\title{
Changes in volatile composition and sensory properties of Iranian ultrafiltered white cheese as affected by blends of Rhizomucor miehei protease or camel chymosin
}

\author{
M. Soltani, ${ }^{*}$ D. Sahingil, $\dagger$ Y. Gokce, $\nmid$ and A. A. Hayaloglu $\dagger^{1}$ \\ *Department of Food Sciences \& Technology, Faculty of Advanced Sciences \& Technology, Pharmaceutical Sciences Branch, \\ Islamic Azad University, 19395-6466 Tehran-Iran (IAUPS) \\ †Department of Food Engineering, Faculty of Engineering, Inonu University, 44280 Malatya, Turkey
}

\begin{abstract}
The effect of using various combinations of Rhizomucor miehei protease and camel chymosin (100:0, $75: 25,50: 50,25: 75$, and 0:100, respectively) on volatile composition and sensory scores in Iranian ultrafiltered white cheese was studied during $90 \mathrm{~d}$ of ripening. A solid-phase microextraction-gas chromatography-mass spectrometric method was used for determining the volatile compounds of the cheeses. Forty compounds including esters (12), acids (6), ketones (9), alcohols (3), and miscellaneous compounds (10) were identified. The main classes of volatile components in the cheeses are esters, miscellaneous compounds, and ketones. The type and concentration of the coagulants influenced both volatile composition and sensory scores of the cheeses. Principal component analysis separated the cheeses based on the use of 2 coagulants in various combinations and ripening time. The cheeses produced using higher concentrations of $R$. miehei were separately located on the plot compared with the cheeses produced using higher concentrations of camel chymosin. Sensory evaluation of the cheeses showed that, in general, the cheeses produced using higher concentrations of camel chymosin received higher body and texture and odor and flavor scores than the cheese produced using higher concentrations of $R$. miehei. In conclusion, 2 combinations of $R$. miehei and camel chymosin (75:25 and 25:75, respectively) can be successfully used for the production of Iranian ultrafiltered white cheese, considering the results of volatile composition and sensory analysis. Key words: ultrafiltered cheese, rennet, milk clotting, ripening
\end{abstract}

Received March 16, 2016.

Accepted June 12, 2016.

${ }^{1}$ Corresponding author: adnan.hayaloglu@inonu.edu.tr

\section{INTRODUCTION}

Activity of milk coagulating enzymes is one of the most important parameters leading to degradation of casein to smaller peptides and free AA. Development of specific and characteristic flavor in cheese is dependent on further degradation of AA to various volatile compounds (i.e., alcohols, aldehydes, acids, and esters; Broome et al., 2006; Yuceer et al., 2009).

Catabolism of protein, lipid, and lactose have important roles in generation of volatile compounds in cheese. In this context, starter and nonstarter lactic acid bacteria (LAB) and coagulating enzymes, which are used for production and ripening of cheese, are able to transform protein, fat, lactose, and citrate into volatile compounds. Furthermore, LAB and abovementioned enzymes may also be responsible for formation of essential aroma compounds in cheese. A balance between various volatile compounds eventually resulted in desirable cheese aroma (Bintsis and Robinson, 2004; Atasoy and Türkoğlu, 2008; Yuceer et al., 2009).

Conversely, sensory characteristics of cheese are changed by the parameters influencing proteolysis during ripening. The extent of proteolysis during manufacturing and ripening and the level of casein degradation to peptides and AA can change the body, texture, and color of cheese (Sousa et al., 2001; Lucey et al., 2003; Broome et al., 2006). During proteolysis, formation of new carboxylic acids and amino groups may lead to changes in water-binding capacity in the cheese mass and consequently lead to decreased water activity and softening of cheese texture. The texture of cheese may also be affected by liberation of ammonia from AA and increases in pH (McSweeney, 2004; Hesari et al., 2007).

Bovine chymosin is the preferred enzyme for using in the cheese manufacturing process for various reasons, including (1) high specificity for $\kappa-\mathrm{CN},(2)$ optimal activity at mildly acidic conditions, (3) optimal flavor development, and (4) provides conditions for formation of strong curd and obtaining high yield (Kappeler et al., 2006). However, due mainly to high cost, bovine 
chymosin has been substituted by enzymes originating from animals (bovine or porcine pepsin), microorganisms (Rhizomucor miehei, Rhizomucor pusillus, and Cryphonectria parasitica), or plant proteases (Hayaloglu et al., 2014). Camel chymosin (CC) is a coagulating enzyme that has been tested as a coagulant for the manufacturing of Cheddar and mozzarella cheeses, previously (Bansal et al., 2009; Moynihan et al., 2014). It has been reported that although the clotting activity of $\mathrm{CC}$ is higher than bovine chymosin on bovine milk, the overall proteolytic activity of this coagulant is not as strong as in clotting activity in cheese (Bansal et al., 2009; Moynihan et al., 2014).

Ultrafiltered white cheese has the highest industrial manufacturing volume and marketing share among the cheese varieties produced in Iran. It is produced in dairy plants using UF-treated and pasteurized bovine milk, mesophilic starter cultures, and Rhizomucor miehei protease (Karami et al., 2009; Soltani et al., 2015). Ultrafiltered cheeses are characterized by their mild flavor and semihard texture, probably due to slower proteolysis occurring inhibiting the proteolytic activity of coagulant added into the retentate by whey proteins, which are present in high concentration in the curd (Hesari et al., 2007). Clotting power and proteolytic actions of $R$. miehei protease and $\mathrm{CC}$ are different. Consequently, the effects of these enzymes on the catabolism of AA to volatile compounds are different (Yuceer et al., 2009; Soltani et al., 2016). To our knowledge, no study has been completed on the evaluation of volatile characteristics of Iranian UF white cheese. The objective of the current work was to determine the effects of different blends of $R$. miehei protease and CC as coagulating enzymes on the volatile composition and sensory properties of Iranian UF white cheese during $90 \mathrm{~d}$ of ripening.

\section{MATERIALS AND METHODS}

\section{Material}

Raw cow milk was obtained from a dairy plant (Damaneh Sahand Co. Inc., Tabriz, Iran) and all equipment for the production of retentate were provided by the same dairy plant. Mesophilic homofermentative culture containing Lactococcus lactis ssp. lactis plus Lactococcus lactis ssp. cremoris (DM-230, Danisco Deutschland GmbH, Niebüll, Germany) and milk-clotting enzymes, including $R$. miehei protease [Fromase 2200 TL Granualte, $\geq 2,200$ international milk clotting units/g, DSM Food Specialties, Seclin, Cedex, France] and CC (CHYMAX M, 1,000 international milk clotting units/mL, Chr. Hansen A/S, Hørsholm, Denmark) were used.

\section{Cheesemaking Procedure}

Ultrafiltered white cheese samples were produced in Damaneh Sahand dairy plant (Tabriz, Iran) in 2 separate trials of consecutive weeks according to the method introduced by Tetra-Pak Inc. (Bylund, 1995). Production of cheeses was implemented according to the procedure described in Soltani et al. (2016). An UF system with receiving capacity of $5 \mathrm{t} / \mathrm{h}$ of milk was used for cheese production. After the UF process, 1 $\mathrm{kg}$ of retentate was obtained from $5.1 \mathrm{~kg}$ of raw milk. For each trial of cheeses production, $10 \mathrm{~kg}$ of obtained retentate was divided in 5 equal parts $(2 \mathrm{~kg}$ for each cheese) after heat treatment $\left(78^{\circ} \mathrm{C}, 1 \mathrm{~min}\right)$, homogenization (at $5 \mathrm{MPa}$ ), and adding starter culture (20 $\mathrm{g} / 1,000 \mathrm{~kg}$ of retentate). The experimental design was implemented according to milk clotting activity of the enzymes, as follows:

- Cheese A: $100 \%$ of R. miehei $+0 \%$ of CC (32 g of R. miehei per 1,000 kg of retentate);

- Cheese B: $75 \%$ of $R$. miehei $+25 \%$ of CC (24 g of R. miehei $+12 \mathrm{~g}$ of CC per $1,000 \mathrm{~kg}$ of retentate);

- Cheese C: $50 \%$ of $R$. miehei $+50 \%$ of CC (16 g of R. miehei $+24 \mathrm{~g}$ of CC per $1,000 \mathrm{~kg}$ of retentate);

- Cheese D: $25 \%$ of $R$. miehei $+75 \%$ of CC (8 g of R. miehei $+36 \mathrm{~g}$ of $\mathrm{CC}$ per $1,000 \mathrm{~kg}$ of retentate); and

- Cheese E: $0 \%$ of R. miehei $+100 \%$ of CC (48 g of CC per $1,000 \mathrm{~kg}$ of retentate).

Sampling of cheeses for analysis was performed on the $\mathrm{d} 1,30,60$, and 90 of ripening according to the procedure described previously by Hayaloglu et al. (2013).

\section{Volatile Compounds Analysis}

Volatile compounds in experimental cheeses were analyzed manually using a solid-phase microextraction fiber in a GC-MS system (Shimadzu GC-2010 gas chromatography and QP-2010 mass spectrometry system; Shimadzu Corp., Kyoto, Japan). Separation was achieved with DB-Wax column $(60 \mathrm{~m} \times 0.25 \mathrm{~mm}$ $\times 0.25 \mathrm{~mm}$; J\&W Scientific, Folsom, CA) run in splitless mode. Flow rate of He, used as carrier gas, was $1.0 \mathrm{~mL} / \mathrm{min}$. Temperature program was performed as described in Hayaloglu et al. (2013). For evaluation of the chromatograms, Wiley 8 (8th ed., John Wiley \& Sons Inc., 2005) and NIST05 mass spectral libraries (http://www.nist.gov) were used to identify the peaks. To confirm retention indices, n-alkane $(\mathrm{C} 8-\mathrm{C} 20)$ series were used by the same conditions. Identifications were also confirmed by comparing retention times with reference standards when available. The concentrations 
were calculated by the comparison of the peak areas of the internal standard containing $81 \mathrm{mg} / \mathrm{L}$ of 2-methyl3-heptanone and 2-methyl pentanoic acid in methanol (Sigma-Aldrich Co., St. Louis, MO) and unknown compounds. Each compound was expressed as micrograms per $100 \mathrm{~g}$ of cheese.

\section{Sensory Analysis}

Sensory evaluation of the cheeses was performed using an evaluation form after $1,30,60$, and $90 \mathrm{~d}$ of ripening by 9 panelists from the members of Damaneh Sahand dairy plant (Tabriz, Iran) that were familiar with UF white cheese. The cheeses in containers with a capacity of $350 \mathrm{~g}$ were used in sensory analysis. The cheeses were graded on a 20-point scale as follows: 0 to 5 points for color and appearance, 0 to 5 points for body and texture (firmer cheese got higher scores), and 0 to 10 points for odor (creamy and sweaty) and flavor (saltiness, acidity, and bitterness); more desirable cheeses got higher scores. Furthermore, total score as the sum of sensory points given to each cheese was calculated during ripening (Mirzaei et al., 2012). About half an hour before evaluation, the coded cheeses were removed from the cold room and kept at room temperature. The cheeses were cut from center and about $100 \mathrm{~g}$ of cheese was presented to each member. Water was also provided to panelists to rinse their mouths between samples (Hayaloglu et al., 2005).

\section{Statistical Analysis}

The volatile and sensory scores obtained from 2 cheesemaking trials were statistically analyzed using the ANOVA of SPSS (ver. 16.0, SPSS Inc., Chicago, IL) after 1,30,60, and $90 \mathrm{~d}$ of ripening. Duncan's multiple range tests were used for analyzing different groups. The obtained results of sensory analysis were considered significant at $\alpha=0.05$ and $\alpha=0.01$. Principal component analysis (PCA) was performed using a covariance matrix and varimax rotation between the cheeses the PCA was carried out using SPSS (ver. 9.0, SPSS Inc.)

\section{RESULTS AND DISCUSSION}

\section{Volatile Composition}

Esters. Esters have low perception threshold and their presence in cheese may cause a decrease in the sharpness of fatty acids and the bitterness of amines (Pinho et al., 2003; McSweeney, 2004; Hayaloglu et al., 2013). In the present study, a total of 12 esters were identified and these were the most abundant chemi- cal compounds contributing to UF white cheese aroma (Table 1). Ethyl acetate, 2-methylpropyl isobutyrate, and 1,1-dimethylpropyl ester were detected as predominant esters compared with others in the cheeses. As shown in Table 1, various blends of $R$. miehei protease and CC significantly $(P<0.01)$ influenced the concentration of all esters during ripening. In this context, the concentrations of ethyl butanoate, 2-methylpropyl isobutyrate, isobutyl butanoate, and 1-methoxy2-propyl acetate in the cheese produced using $100 \%$ of CC (cheese E) were higher than those of the cheese produced using $100 \%$ of $R$. miehei protease (cheese A) at the end of ripening. Conversely, some fluctuations were observed for the most compounds during ripening of the cheeses. Ripening time significantly influenced $(\alpha<0.05$ or 0.01$)$ the concentration of all esters except methyl-2-methylpropanoate, isopropyl pentanoate, and butyl isobutanoate.

Ketones. Nine ketones were determined in UF white cheeses during ripening (Table 2). 2-Propanone, 2-butanone, 2,3-butandione, and 3-hydroxy-2-butanone were the major ketones detected at substantial levels in all cheeses during ripening.

The concentration of 2-butanone (butter flavor) increased during ripening in all cheeses and was influenced significantly $(P<0.01)$ by both type and blends levels of coagulant and also ripening time. 2-Butanone was also detected as the principal ketone in Teleme (Massouras et al., 2006), raw goat milk (Delgado et al., 2011), and Gokceada cheeses (Hayaloglu et al., 2013). 2,3-Butandione is produced through metabolism of citrate by LAB and is then reduced to 3-hydroxy2-butanone in cheese (Bintsis and Robinson, 2004). In addition to principal ketones in UF white cheese, acetaldehyde, hexanal, 2-heptanone, 4-octanone, and 2 -methyl pentanal were also identified at substantial levels. Acetaldehyde was determined at highest level at the end of ripening in all cheeses. Metabolism of lactate or oxidation of ethanol may have led to formation of acetaldehyde in the experimental cheeses (McSweeney and Sousa, 2000). 2-Heptanone with herbaceous odor was detected for all cheeses and affected by ripening time significantly $(P<0.05)$. Thus, the concentration of 2-heptanone increased compared with the first day in all experimental cheeses toward the end of ripening. However, the concentration of this compound during ripening was not significantly affected by the changes in type or concentration of coagulants used for manufacturing of the cheeses.

Acids. In the present study, acetic, butanoic, hexanoic, and octanoic acids were the most abundant volatile acids in the cheese samples, suggesting that they are the major contributors to overall volatile compounds (probably aroma) of the UF white cheese (Table 3). 
Table 1. Esters $(\mu \mathrm{g} / 100 \mathrm{~g})$ in Iranian UF white cheeses produced from different combinations of Rhizomucor miehei protease and camel chymosin [CC; $100 \%$ of $R$. miehei protease $+0 \%$ of CC (A), $75 \%$ of $R$. miehei protease $+25 \%$ of CC (B), $50 \%$ of $R$. miehei protease $+50 \%$ of CC (C), $25 \%$ of $R$. miehei protease $+75 \%$ of CC (D) and $0 \%$ of $R$. miehei protease $+100 \%$ of CC (E)] during $90 \mathrm{~d}$ of ripening ${ }^{1}$

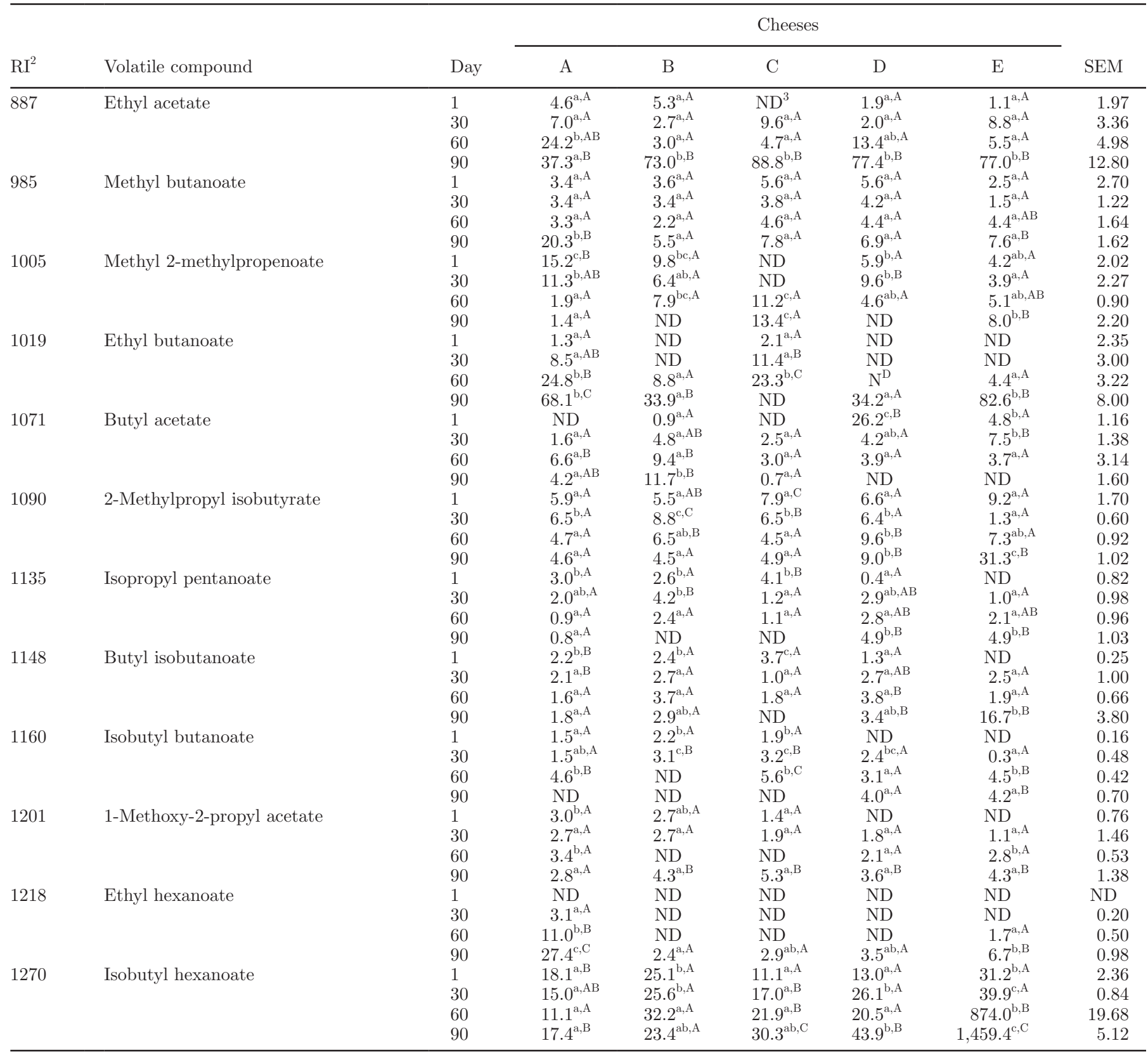

${ }^{\mathrm{a}-\mathrm{c}}$ Means with different superscripts within each sample for each of the parameters measured are different $(P<0.05)$.

${ }^{\mathrm{A}-\mathrm{C}}$ Means with different superscripts within each ripening time for each of the parameters measured are different $(P<0.05)$.

${ }^{1}$ Values are shown as mean of 2 separate samples from 2 batches.

${ }^{2}$ Retention index.

${ }^{3}$ Not detected.

The use of $R$. miehei protease and CC significantly $(P$ $<0.01$ ) influenced the concentration of acids at various stages of ripening. The cheese produced using $100 \%$ of $R$. miehei protease (cheese A) contained higher levels of acetic acid, isobutyric acid, and butanoic acid compared with the cheese produced using $100 \%$ of CC (cheese E). Higher proteolytic activity of $R$. miehei protease compared with CC may have caused a decrease in the presence of proteinaceous compounds in cheese mass and an increase in the concentrations of volatile 
acids (Sousa and Malcata, 2002; Tavaria et al., 2006). Whereas hexanoic acid was the dominant carboxylic acid in the cheese produced using $100 \%$ of CC (cheese E) during ripening, acetic acid was detected as predominant volatile acid in the other cheeses at any stage of ripening. The levels of octanoic acid in the cheese produced using $100 \%$ of CC (cheese E) were significantly $(P<0.01)$ higher than that of the cheese produced using $100 \%$ of $R$. miehei protease (cheeses A) after 30, 60 , and $90 \mathrm{~d}$ of ripening. A similar trend was observed for decanoic acid after 60 and $90 \mathrm{~d}$ of ripening. It was reported that short-chain volatile acids, such as acetic, butanoic, hexanoic, octanoic, and decanoic acids, had significant effects on the flavor of cheese (Attaie and
Richter, 1996; Yilmaz et al., 2005). The results also showed that the contents of all volatile acids, except isobutyric and octanoic acids, increased significantly $(P$ $<0.01$ ) during ripening in all cheeses. In similar cases, increasing the concentration of fatty acids during ripening was reported for Serra da Estrela cheese (Tavaria et al., 2004) and Iranian white brine cheese (Alizadeh et al., 2006). Direct biosynthesis from acetyl-CoA and by metabolism of lactose are the main pathways for the formation of free fatty acids in cheese along with the progress of ripening (Tavaria et al., 2004).

Alcohols. Only 3 alcohols were detected in UF white cheese during ripening and it was determined that alcohols are not a major contributor for the aroma of

Table 2. Ketones $(\mu \mathrm{g} / 100 \mathrm{~g})$ in Iranian UF white cheeses produced from different combinations of Rhizomucor miehei protease and camel chymosin [CC; $100 \%$ of $R$. miehei protease $+0 \%$ of CC (A), $75 \%$ of $R$. miehei protease $+25 \%$ of CC (B), $50 \%$ of $R$. miehei protease $+50 \%$ of $\mathrm{CC}(\mathrm{C}), 25 \%$ of $R$. miehei protease $+75 \%$ of $\mathrm{CC}(\mathrm{D})$ and $0 \%$ of $R$. miehei protease $+100 \%$ of CC (E)] during $90 \mathrm{~d}^{\text {of ripening }}{ }^{1}$

\begin{tabular}{|c|c|c|c|c|c|c|c|c|}
\hline \multirow[b]{2}{*}{$\mathrm{RI}^{2}$} & \multirow[b]{2}{*}{ Name } & \multirow[b]{2}{*}{ Day } & \multicolumn{5}{|c|}{ Cheese } & \multirow[b]{2}{*}{ SEM } \\
\hline & & & $\mathrm{A}$ & B & $\mathrm{C}$ & $\mathrm{D}$ & $\mathrm{E}$ & \\
\hline \multirow[t]{4}{*}{745} & \multirow[t]{4}{*}{ Acetaldehyde } & 1 & $1.4^{\mathrm{ab}, \mathrm{A}}$ & $2.8^{\mathrm{b}, \mathrm{A}}$ & $\mathrm{ND}^{3}$ & $\mathrm{ND}$ & $\mathrm{ND}$ & 1.15 \\
\hline & & 30 & $4.2^{\mathrm{a}, \mathrm{A}}$ & $3.7^{\mathrm{a}, \mathrm{A}}$ & ND & $1.9^{\mathrm{a}, \mathrm{AB}}$ & $3.7^{\mathrm{a}, \mathrm{A}}$ & 1.42 \\
\hline & & 60 & $3.4^{\mathrm{a}, \mathrm{A}}$ & $4.6^{\mathrm{a}, \mathrm{A}}$ & $3.9^{\mathrm{a}, \mathrm{A}}$ & $4.6^{\mathrm{a}, \mathrm{AB}}$ & $4.8^{\mathrm{a}, \mathrm{A}}$ & 1.38 \\
\hline & & 90 & $11.5^{\mathrm{a}, \mathrm{B}}$ & $8.2^{\mathrm{b}, \mathrm{B}}$ & $10.1^{\mathrm{ab}, \mathrm{B}}$ & $5.5^{\mathrm{c}, \mathrm{B}}$ & $5.1^{\mathrm{c}, \mathrm{A}}$ & 0.86 \\
\hline \multirow[t]{4}{*}{815} & \multirow[t]{4}{*}{ 2-Propanone } & 1 & $60.1^{\mathrm{ab}, \mathrm{A}}$ & $80.4^{\mathrm{b}, \mathrm{A}}$ & $48.8^{\mathrm{a}, \mathrm{A}}$ & $43.3^{\mathrm{a}, \mathrm{A}}$ & $54.9^{\mathrm{ab}, \mathrm{B}}$ & 8.66 \\
\hline & & 30 & $74.2^{\mathrm{a}, \mathrm{A}}$ & $140.2^{\mathrm{b}, \mathrm{B}}$ & $112.8^{\mathrm{ab}, \mathrm{B}}$ & $94.8^{\mathrm{ab}, \mathrm{B}}$ & $77.3^{\mathrm{a}, \mathrm{C}}$ & 14.76 \\
\hline & & 60 & $98.3^{\mathrm{a}, \mathrm{AB}}$ & $145.9^{\mathrm{b}, \mathrm{B}}$ & $104.7^{\mathrm{a}, \mathrm{B}}$ & $103.9^{\mathrm{a}, \mathrm{B}}$ & $140.4^{\mathrm{b}, \mathrm{D}}$ & 20.48 \\
\hline & & 90 & $121.6^{\mathrm{b}, \mathrm{B}}$ & $156.9^{\mathrm{b}, \mathrm{B}}$ & $201.7^{\mathrm{b}, \mathrm{C}}$ & $160.8^{\mathrm{b}, \mathrm{C}}$ & $25.8^{\mathrm{a}, \mathrm{A}}$ & 25.96 \\
\hline \multirow[t]{4}{*}{793} & \multirow[t]{4}{*}{ 2-Butanone } & 1 & $16.6^{\mathrm{ab}, \mathrm{A}}$ & $8.7^{\mathrm{a}, \mathrm{A}}$ & $10.1^{\mathrm{a}, \mathrm{A}}$ & $29.2^{\mathrm{c}, \mathrm{A}}$ & $22.1^{\mathrm{bc}, \mathrm{A}}$ & 3.80 \\
\hline & & 30 & $21.4^{\mathrm{ab}, \mathrm{A}}$ & $25.3^{\mathrm{b}, \mathrm{AB}}$ & $15.2^{\mathrm{a}, \mathrm{A}}$ & $27.8^{\mathrm{b}, \mathrm{A}}$ & $50.1^{\mathrm{c}, \mathrm{B}}$ & 2.58 \\
\hline & & 60 & $38.5^{\mathrm{b}, \mathrm{A}}$ & $40.3^{\mathrm{b}, \mathrm{B}}$ & $24.5^{\mathrm{a}, \mathrm{A}}$ & $29.8^{\mathrm{ab}, \mathrm{A}}$ & $50.1^{\mathrm{b}, \mathrm{B}}$ & 7.22 \\
\hline & & 90 & $65.7^{\mathrm{a}, \mathrm{B}}$ & $41.4^{\mathrm{a}, \mathrm{B}}$ & $48.4^{\mathrm{a}, \mathrm{B}}$ & $55.6^{\mathrm{a}, \mathrm{B}}$ & $59.0^{\mathrm{a}, \mathrm{B}}$ & 12.16 \\
\hline \multirow[t]{4}{*}{973} & \multirow[t]{4}{*}{ 2,3-Butanedione } & 1 & $85.2^{\mathrm{a}, \mathrm{A}}$ & $270.3^{\mathrm{b}, \mathrm{B}}$ & $74.7^{\mathrm{a}, \mathrm{A}}$ & $82.7^{\mathrm{a}, \mathrm{A}}$ & $86.2^{\mathrm{a}, \mathrm{A}}$ & 13.66 \\
\hline & & 30 & $88.4^{\mathrm{a}, \mathrm{A}}$ & $65.9^{\mathrm{a}, \mathrm{A}}$ & $110.7^{\mathrm{a}, \mathrm{A}}$ & $99.0^{\mathrm{a}, \mathrm{AB}}$ & $87.1^{\mathrm{a}, \mathrm{A}}$ & 19.94 \\
\hline & & 60 & $115.6^{\mathrm{ab}, \mathrm{B}}$ & $60.2^{\mathrm{a}, \mathrm{A}}$ & $217.0^{\mathrm{c}, \mathrm{B}}$ & $115.9^{\mathrm{ab}, \mathrm{B}}$ & $156.7^{\mathrm{bc}, \mathrm{B}}$ & 26.60 \\
\hline & & 90 & $245.2^{\mathrm{b}, \mathrm{B}}$ & $184.6^{\mathrm{a}, \mathrm{B}}$ & $261.0^{\mathrm{b}, \mathrm{B}}$ & $149.5^{\mathrm{a}, \mathrm{C}}$ & $150.2^{\mathrm{a}, \mathrm{B}}$ & 50.76 \\
\hline \multirow[t]{4}{*}{1083} & \multirow[t]{4}{*}{ Hexanal } & 1 & $6.6^{\mathrm{a}, \mathrm{A}}$ & $2.6^{\mathrm{c}, \mathrm{A}}$ & $3.8^{\mathrm{b}, \mathrm{A}}$ & $3.4^{\mathrm{bc}, \mathrm{AB}}$ & ND & 0.45 \\
\hline & & 30 & $5.9^{\mathrm{a}, \mathrm{AB}}$ & $2.9^{\mathrm{a}, \mathrm{A}}$ & $5.2^{\mathrm{a}, \mathrm{A}}$ & $5.6^{\mathrm{a}, \mathrm{BC}}$ & $1.6^{\mathrm{a}, \mathrm{A}}$ & 1.04 \\
\hline & & 60 & $4.0^{\mathrm{a}, \mathrm{AB}}$ & $8.2^{\mathrm{b}, \mathrm{B}}$ & $12.2^{\mathrm{b}, \mathrm{B}}$ & $2.1^{\mathrm{a}, \mathrm{A}}$ & $4.1^{\mathrm{a}, \mathrm{A}}$ & 1.46 \\
\hline & & 90 & $2.9^{\mathrm{a}, \mathrm{B}}$ & ND & ND & $7.3^{\mathrm{b}, \mathrm{C}}$ & $16.5^{\mathrm{c}, \mathrm{B}}$ & 1.86 \\
\hline \multirow[t]{4}{*}{1185} & \multirow[t]{4}{*}{ 2-Heptanone } & 1 & $5.6^{\mathrm{b}, \mathrm{A}}$ & $15.5^{\mathrm{c}, \mathrm{A}}$ & $13.2^{\mathrm{bc}, \mathrm{A}}$ & $4.8^{\mathrm{a}, \mathrm{A}}$ & $18.8^{\mathrm{c}, \mathrm{A}}$ & 2.08 \\
\hline & & 30 & $14.9^{\mathrm{a}, \mathrm{B}}$ & $22.7^{\mathrm{a}, \mathrm{A}}$ & $20.6^{\mathrm{a}, \mathrm{AB}}$ & $16.3^{\mathrm{a}, \mathrm{B}}$ & $19.5^{\mathrm{a}, \mathrm{A}}$ & 1.56 \\
\hline & & 60 & $24.8^{\mathrm{ab}, \mathrm{C}}$ & $17.4^{\mathrm{a}, \mathrm{A}}$ & $25.3^{\mathrm{ab}, \mathrm{BC}}$ & $32.0^{\mathrm{b}, \mathrm{C}}$ & $18.5^{\mathrm{a}, \mathrm{A}}$ & 2.50 \\
\hline & & 90 & $31.1^{\mathrm{b}, \mathrm{C}}$ & $20.4^{\mathrm{a}, \mathrm{A}}$ & $32.9^{\mathrm{b}, \mathrm{C}}$ & $36.0^{\mathrm{b}, \mathrm{C}}$ & $30.6^{\mathrm{b}, \mathrm{B}}$ & 3.02 \\
\hline \multirow[t]{4}{*}{1234} & \multirow[t]{4}{*}{ 4-Octanone } & 1 & $4.3^{\mathrm{b}, \mathrm{A}}$ & $5.8^{\mathrm{b}, \mathrm{A}}$ & $5.4^{\mathrm{b}, \mathrm{AB}}$ & $2.4^{\mathrm{a}, \mathrm{A}}$ & ND & 0.65 \\
\hline & & 30 & $4.7^{\mathrm{ab}, \mathrm{A}}$ & $7.6^{\mathrm{bc}, \mathrm{A}}$ & $8.5^{\mathrm{c}, \mathrm{B}}$ & $6.2^{\mathrm{bc}, \mathrm{AB}}$ & $2.9^{\mathrm{a}, \mathrm{A}}$ & 1.06 \\
\hline & & 60 & $3.5^{\mathrm{a}, \mathrm{A}}$ & $4.8^{\mathrm{a}, \mathrm{A}}$ & $1.6^{\mathrm{a}, \mathrm{A}}$ & $4.6^{\mathrm{a}, \mathrm{AB}}$ & $5.0^{\mathrm{a}, \mathrm{AB}}$ & 1.42 \\
\hline & & 90 & $4.4^{\mathrm{a}, \mathrm{A}}$ & $6.5^{\mathrm{ab}, \mathrm{A}}$ & $4.3^{\mathrm{a}, \mathrm{AB}}$ & $8.5^{\mathrm{b}, \mathrm{B}}$ & $7.0^{\mathrm{ab}, \mathrm{B}}$ & 1.06 \\
\hline \multirow[t]{4}{*}{1291} & \multirow{4}{*}{$\begin{array}{l}\text { 3-Hydroxy-2- } \\
\text { butanone }\end{array}$} & 1 & $299.7^{\mathrm{b}, \mathrm{A}}$ & $256.8^{\mathrm{ab}, \mathrm{A}}$ & $449.2^{\mathrm{c}, \mathrm{A}}$ & $258.9^{\mathrm{ab}, \mathrm{A}}$ & $244.3^{\mathrm{a}, \mathrm{A}}$ & 13.52 \\
\hline & & 30 & $558.1^{\mathrm{bc}, \mathrm{B}}$ & $613.7^{\mathrm{c}, \mathrm{B}}$ & $452.3^{\mathrm{b}, \mathrm{A}}$ & $278.6^{\mathrm{a}, \mathrm{A}}$ & $297.2^{\mathrm{a}, \mathrm{AB}}$ & 31.08 \\
\hline & & 60 & $523.1^{\mathrm{b}, \mathrm{B}}$ & $668.9^{\mathrm{b}, \mathrm{B}}$ & $944.5^{\mathrm{c}, \mathrm{B}}$ & $659.6^{\mathrm{b}, \mathrm{B}}$ & $321.9^{\mathrm{a}, \mathrm{B}}$ & 36.80 \\
\hline & & 90 & $718.2^{\mathrm{a}, \mathrm{C}}$ & $1712.2 \mathrm{~d}^{, \mathrm{C}}$ & $1284.7^{\mathrm{c}, \mathrm{C}}$ & $898.5^{\mathrm{b}, \mathrm{C}}$ & $749.5^{\mathrm{ab}, \mathrm{C}}$ & 49.54 \\
\hline \multirow[t]{4}{*}{1401} & \multirow[t]{4}{*}{ 2-Methyl pentanal } & 1 & ND & ND & ND & ND & ND & ND \\
\hline & & 30 & ND & ND & $3.9^{\mathrm{a}, \mathrm{A}}$ & ND & $3.7^{\mathrm{a}, \mathrm{A}}$ & 1.45 \\
\hline & & 60 & $2.6^{\mathrm{a}, \mathrm{A}}$ & $2.5^{\mathrm{a}, \mathrm{A}}$ & $10.0^{\mathrm{c}, \mathrm{C}}$ & ND & $4.2^{\mathrm{b}, \mathrm{A}}$ & 1.15 \\
\hline & & 90 & $2.9^{\mathrm{a}, \mathrm{A}}$ & $4.2^{\mathrm{ab}, \mathrm{B}}$ & $5.4^{\mathrm{b}, \mathrm{B}}$ & $3.5^{\mathrm{a}, \mathrm{A}}$ & $3.4^{\mathrm{a}, \mathrm{A}}$ & 0.52 \\
\hline
\end{tabular}

\footnotetext{
${ }^{\mathrm{a}-\mathrm{c}}$ Means with different superscripts within each sample for each of the parameters measured are different $(P<0.05)$.

${ }^{\mathrm{A}-\mathrm{C}}$ Means with different superscripts within each ripening time for each of the parameters measured are different $(P<0.05)$.

${ }^{1}$ Values are shown as mean of 2 separate samples from 2 batches.

${ }^{2}$ Retention index.

${ }^{3}$ Not detected.
} 
Table 3. Acids ( $\mu \mathrm{g} / 100 \mathrm{~g})$ in Iranian UF white cheeses produced from different combinations of Rhizomucor miehei protease and camel chymosin [CC; $100 \%$ of $R$. miehei protease $+0 \%$ of CC (A), $75 \%$ of $R$. miehei protease $+25 \%$ of CC (B), $50 \%$ of $R$. miehei protease $+50 \%$ of CC (C), $25 \%$ of $R$. miehei protease $+75 \%$ of $\mathrm{CC}$ (D) and $0 \%$ of $R$. miehei protease $+100 \%$ of CC (E)] during $90 \mathrm{~d}_{\text {of ripening }}{ }^{1}$

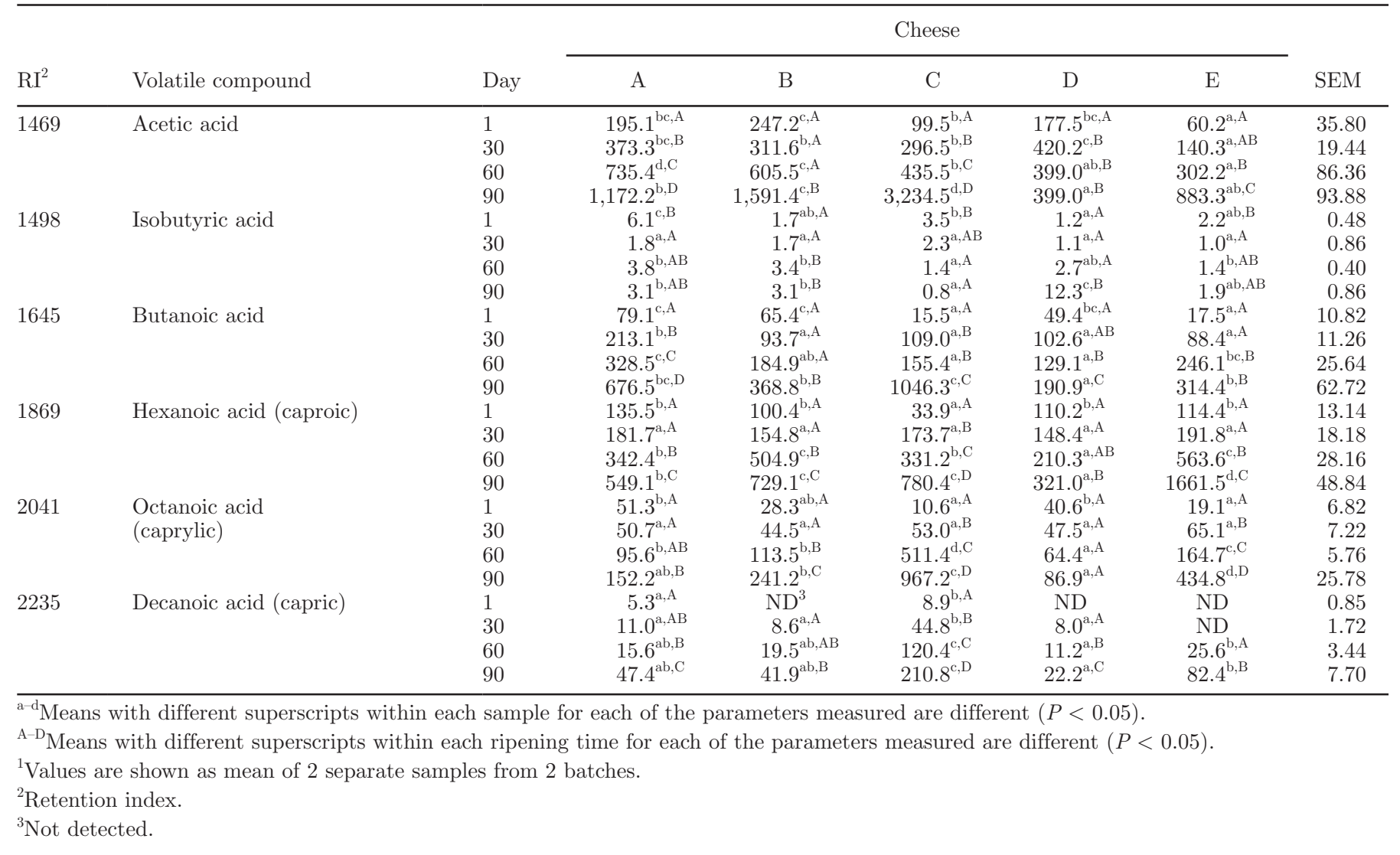

Iranian UF cheese. Use of different combinations of $R$. miehei protease and CC significantly influenced $(P$ $<0.05)$ the concentrations of alcohols in the cheeses during ripening (Table 4). Ethanol, 1-hexanol, and 2-methyl-2-propanol were determined in the cheeses at various concentrations during ripening. Ethanol was the most abundant alcohol in all samples. The highest ethanol concentration was determined in the cheese produced using $100 \%$ of $R$. miehei protease (cheese A) after 60 and 90 of ripening. Fermentation of lactose and the catabolism of Ala may have led to production of ethanol and it has also an important role in formation of esters (Hayaloglu et al., 2013). Ethanol was also determined as one of the main alcohol compounds in feta-type, Gokceada, and Cheddar cheeses (Bintsis and Robinson, 2004; Hayaloglu et al., 2013; Hou et al., 2014). Conversely, the amounts of 1-hexanol and 2-mehyl-2-propanol were lower than ethanol and fluctuated during ripening. Continuous degradation by different metabolic pathways during ripening of cheese, especially catabolism of aldehydes, may led to formation of alcohol compounds in different concentrations
(McSweeney and Sousa, 2000; Hayaloglu et al., 2013; Hou et al., 2014).

Miscellaneous Compounds. Ten miscellaneous compounds were identified in the experimental cheeses (Table 5). Ethyl ether, methylamine-D2, toluene, 1-limonene, and styrene were predominant compounds for all cheeses, especially after 60 and $90 \mathrm{~d}$ of ripening. The type and concentration of the coagulants significantly $(P<0.01)$ influenced the intensities of 3-methyl-1-butene, methylamine-D2, toluene, 1-limonene, and styrene during ripening. However, changes in the levels of these compounds did not follow the same trend during ripening in some cases. For example, the level of ethyl ether in the cheeses produced with higher concentrations of CC (cheeses D and E) was detected at higher levels than the cheeses produced with higher concentrations of $R$. miehei protease (cheeses A and $\mathrm{B}$ ) after 30 and $60 \mathrm{~d}$ of ripening. Nevertheless, at the end of ripening, higher levels of ethyl ether were detected in the cheese produced with higher concentrations of R. miehei protease (cheese A and B). Detection of dimethyl sulfide in the cheeses is a worth noting. 
Table 4. Alcohols $(\mu \mathrm{g} / 100 \mathrm{~g})$ in Iranian UF white cheeses produced from different combinations of Rhizomucor miehei protease and camel chymosin [CC; $100 \%$ of $R$. miehei protease $+0 \%$ of CC (A), $75 \%$ of $R$. miehei protease $+25 \%$ of CC (B), $50 \%$ of $R$. miehei protease $+50 \%$ of CC (C), $25 \%$ of $R$. miehei protease $+75 \%$ of CC (D) and $0 \%$ of $R$. miehei protease $+100 \%$ of CC (E)] during $90 \mathrm{~d}$ of ripening ${ }^{1}$

\begin{tabular}{|c|c|c|c|c|c|c|c|c|}
\hline $\mathrm{RI}^{2}$ & Volatile compound & Day & \multicolumn{5}{|c|}{ Cheese } & SEM \\
\hline 907 & Ethanol & $\begin{array}{l}1 \\
30 \\
60 \\
90\end{array}$ & $\begin{array}{r}174.0^{\mathrm{b}, \mathrm{A}} \\
168.5^{\mathrm{b}, \mathrm{A}} \\
587.0^{\mathrm{b}, \mathrm{B}} \\
1,383.6^{\mathrm{c}, \mathrm{C}}\end{array}$ & $\begin{array}{c}156.9^{\mathrm{b}, \mathrm{B}} \\
175.0^{\mathrm{b}, \mathrm{B}} \\
85.6^{\mathrm{a}, \mathrm{A}} \\
197.1^{\mathrm{ab}, \mathrm{B}}\end{array}$ & $\begin{array}{r}171.0^{\mathrm{b}, \mathrm{B}} \\
244.6^{\mathrm{c}, \mathrm{C}} \\
67.5^{\mathrm{a}, \mathrm{A}} \\
240.4^{\mathrm{b}, \mathrm{C}}\end{array}$ & $\begin{array}{c}53.4^{\mathrm{a}, \mathrm{A}} \\
137.5^{\mathrm{a}, \mathrm{B}} \\
118.5^{\mathrm{a}, \mathrm{B}} \\
195.9^{\mathrm{ab}, \mathrm{C}}\end{array}$ & $\begin{array}{l}116.2^{\mathrm{ab}, \mathrm{A}} \\
114.1^{\mathrm{a}, \mathrm{A}} \\
103.6^{\mathrm{a}, \mathrm{A}} \\
138.5^{\mathrm{a}, \mathrm{A}}\end{array}$ & $\begin{array}{l}19.72 \\
72.76 \\
20.24 \\
31.22\end{array}$ \\
\hline 1343 & 1-Hexanol & $\begin{array}{l}1 \\
30 \\
60 \\
90\end{array}$ & $\begin{array}{r}\mathrm{ND}^{3} \\
12.2^{\mathrm{b}, \mathrm{B}} \\
3.7^{\mathrm{a}, \mathrm{A}} \\
10.9^{\mathrm{a}, \mathrm{B}}\end{array}$ & $\begin{array}{c}\text { ND } \\
4.1^{\mathrm{a}, \mathrm{A}} \\
5.3^{\mathrm{a}, \mathrm{A}} \\
13.3^{\mathrm{ab}, \mathrm{B}}\end{array}$ & $\begin{array}{c}\text { ND } \\
2.7^{\mathrm{a}, \mathrm{A}} \\
10.5^{\mathrm{b}, \mathrm{B}} \\
17.5^{\mathrm{b}, \mathrm{C}}\end{array}$ & $\begin{array}{c}\mathrm{ND} \\
2.5^{\mathrm{a}, \mathrm{A}} \\
10.8^{\mathrm{b}, \mathrm{B}} \\
14.0^{\mathrm{ab}, \mathrm{B}}\end{array}$ & $\begin{array}{l}\text { ND } \\
6.3^{\mathrm{a}, \mathrm{A}} \\
9.6^{\mathrm{b}, \mathrm{B}} \\
27.9^{\mathrm{c}, \mathrm{C}}\end{array}$ & $\begin{array}{l}\mathrm{ND} \\
1.26 \\
2.46 \\
2.04\end{array}$ \\
\hline 1501 & 2-Methyl-2-propanol & $\begin{array}{l}1 \\
30 \\
60 \\
90\end{array}$ & $\begin{array}{r}14.3^{\mathrm{b}, \mathrm{B}} \\
8.1^{\mathrm{ab}, \mathrm{A}} \\
10.9^{\mathrm{ab}, \mathrm{A}} \\
8.2^{\mathrm{a}, \mathrm{A}}\end{array}$ & $\begin{array}{c}10.9^{\mathrm{ab}, \mathrm{A}} \\
10.5^{\mathrm{b}, \mathrm{A}} \\
13.3^{\mathrm{b}, \mathrm{B}} \\
9.9^{\mathrm{a}, \mathrm{A}}\end{array}$ & $\begin{array}{c}11.9^{\mathrm{ab}, \mathrm{B}} \\
9.8^{\mathrm{b}, \mathrm{A}} \\
7.2^{\mathrm{a}, \mathrm{A}} \\
8.7^{\mathrm{a}, \mathrm{A}}\end{array}$ & $\begin{array}{c}5.3^{\mathrm{a}, \mathrm{A}} \\
7.9^{\mathrm{ab}, \mathrm{A}} \\
11.2^{\mathrm{ab}, \mathrm{B}} \\
16.9^{\mathrm{ab}, \mathrm{C}}\end{array}$ & $\begin{array}{r}14.6^{\mathrm{b}, \mathrm{B}} \\
5.9^{\mathrm{a}, \mathrm{A}} \\
6.8^{\mathrm{a}, \mathrm{A}} \\
21.0^{\mathrm{b}, \mathrm{C}}\end{array}$ & $\begin{array}{l}3.7 \\
2.5 \\
0.88 \\
1.08\end{array}$ \\
\hline
\end{tabular}

${ }^{\mathrm{a}-\mathrm{c}}$ Means with different superscripts within each sample for each of the parameters measured are different $(P<0.05)$.

${ }^{\mathrm{A}-\mathrm{C}}$ Means with different superscripts within each ripening time for each of the parameters measured are different $(P<0.05)$.

${ }^{1}$ Values are shown as mean of 2 separate samples from 2 batches.

${ }^{2}$ Retention index.

${ }^{3}$ Not detected.

Dimethyl sulfide was reported as an important volatile component in Domiati, parmesan, feta-type, and Ezine cheeses (Collin et al., 1993; Barbieri et al., 1994; Bintsis and Robinson, 2004; Yuceer et al., 2009). Table 5 shows that dimethyl sulfide was detected in all cheese after 1 , 30 , and $60 \mathrm{~d}$ of ripening. Interestingly, it was observed that this volatile compound detected only in the cheese produced using $100 \%$ of CC (cheese E) at the end of ripening. Furthermore, the concentration of ethyl ether, toluene, 1-limonene, and styrene were higher in 90-dold cheeses compared with the younger cheeses.

\section{PCA of the GC-MS Data}

The PCA was applied to the variables obtained from the GC-MS data to explain the effect of various combinations of $R$. miehei protease and CC on volatile profiles of the experimental cheeses after 1,30,60, and $90 \mathrm{~d}$ of ripening. Two principal components (PC) accounted for $47.8 \%$ of the total variance: $\mathrm{PC} 1$ (x-axis) and $\mathrm{PC} 2$ (y-axis) accounted for 32.3 and $15.5 \%$ of the total variance, respectively (Figure 1). The PC1 characterizes ripening time, whereas $\mathrm{PC} 2$ was the sample (i.e., treatment). The type and concentration of coagulants in the different combinations significantly influenced the volatiles of the cheeses; all of the cheeses were located in the negative side of $\mathrm{PC} 1$ at 1 and $30 \mathrm{~d}$ of ripening. However, the differences were clear after $60 \mathrm{~d}$ of ripening, where, with exception of cheeses $\mathrm{B}$ and $\mathrm{D}$, the cheeses were placed in the positive side of PC1. This situation suggested that the cheese produced using 2 combinations of $R$. miehei protease and CC (75:25 and $25: 75$, respectively) were different from other cheese in terms of volatile composition at the $60 \mathrm{~d}$ of ripening. No difference was seen among the old cheeses and all cheeses were located in the positive side of PC1 after $90 \mathrm{~d}$ of ripening. Conversely, in PC2, no clear grouping was observed among the cheeses after 1 and $30 \mathrm{~d}$ of ripening. However, the type and concentration of the coagulant used affected the position of the cheeses after $60 \mathrm{~d}$ of ripening. So that, the differences were observed between the cheese produced using $100 \%$ of $R$. miehei protease (cheese A) and the cheeses produced using higher concentrations of $\mathrm{CC}$ (cheeses D and E) after 60 $\mathrm{d}$ of ripening. In this case, the cheese A was located in the negative side of $\mathrm{PC} 2$, whereas cheeses $\mathrm{D}$ and $\mathrm{E}$ were placed in the positive side of PC2. This trend was continued and significant changes clearly occurred toward the end of ripening in the experimental cheeses because of the type and concentration of coagulants used for production. Whereas the cheeses produced using higher concentrations of $R$. miehei protease (cheeses A and $\mathrm{B})$ were located in the negative side of $\mathrm{PC} 2$, those produced using higher concentrations of $\mathrm{CC}$ (cheeses D and $\mathrm{E}$ ) were located in the positive side of $\mathrm{PC} 2$ after $90 \mathrm{~d}$ of ripening. In general, as ripening progressed, the differences were observed among the experimental cheeses in PC1 and PC2 especially after 60 and $90 \mathrm{~d}$ of ripening. The cheeses were distinguished from left to right side on the PCA plot, highlighting their age, and these distributions were signaled using an arrow (from young to ripe cheese). 


\section{Sensory Evaluation}

The sensory evaluation results of the cheeses during $90 \mathrm{~d}$ of ripening are shown in Table 6. Appearance is directly related to cheese quality and plays an important role in consumer acceptance (Kaya, 2002). Using 2 different coagulants at various combinations had no significant effect $(P>0.05)$ on color and appearance of the cheeses during ripening. In terms of firmness, the body and texture points in the cheeses produced using higher levels of CC (cheeses D and E) were higher than those in the cheeses produced using higher levels of $R$. miehei protease (cheeses $\mathrm{A}$ and $\mathrm{B}$ ). The cheeses produced using higher levels of CC (chesses D and E) had more compact protein network and harder texture compared with other cheeses, probably due to less proteolytic activity of $\mathrm{CC}$ compared with $R$. miehei protease (Soltani et al., 2016). Soodam et al. (2015) reported that Cheddar cheese produced with recombinant CC had a thicker protein network and was harder

Table 5. Miscellaneous compounds ( $\mu \mathrm{g} / 100 \mathrm{~g}$ ) in Iranian UF white cheeses produced from different combinations of Rhizomucor miehei protease and camel chymosin [CC; $100 \%$ of $R$. miehei protease $+0 \%$ of CC (A), $75 \%$ of $R$. miehei protease $+25 \%$ of CC (B), $50 \%$ of $R$. miehei protease $+50 \%$ of CC (C), $25 \%$ of $R$. miehei protease $+75 \%$ of CC (D) and $0 \%$ of $R$. miehei protease $+100 \%$ of CC (E)] during $90 \mathrm{~d}$ of ripening ${ }^{1}$

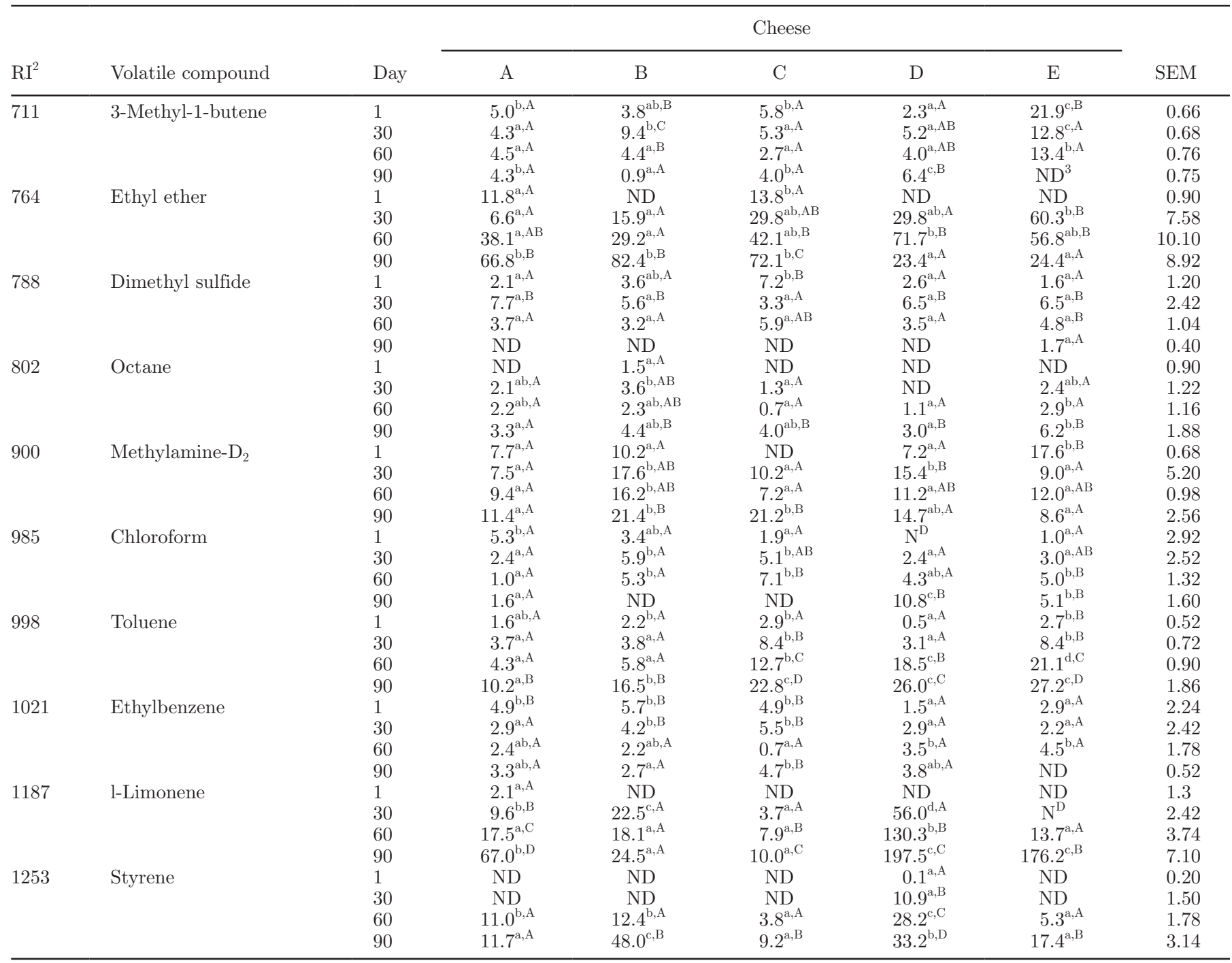

${ }^{\mathrm{a}-\mathrm{c}}$ Means with different superscripts within each sample for each of the parameters measured are different $(P<0.05)$.

${ }^{\mathrm{A}-\mathrm{C}}$ Means with different superscripts within each ripening time for each of the parameters measured are different $(P<0.05)$.

${ }^{1}$ Values are shown as mean of 2 separate samples from 2 batches.

${ }^{2}$ Retention index.

${ }^{3}$ Not detected. 
than the Cheddar produced with microbial rennet (Hannilase, $750 \mathrm{IMCU} \cdot \mathrm{mL}^{-1}$, Chr. Hansen, Bayswater, Australia), probably because of lower proteolytic activity of CC compared with microbial rennet. Similar results have been reported by Bansal et al. (2009) and Govindasamy-Lucey et al. (2010), where the Cheddar cheese was produced using $\mathrm{CC}$ alone or in combination with calf chymosin. The odor and flavor points of the cheeses were significantly $(P<0.05)$ influenced by the type and concentration of the coagulants after 30,60 , and $90 \mathrm{~d}$ of ripening; cheese $\mathrm{E}$ had higher odor and flavor points and was more desirable than other cheeses during ripening. Al-Otaibi and Wilbey (2005) reported that breakdown of proteins and release of proteolysis products at moderate levels may cause formation of acceptable odor and flavor in cheese. Moreover, the cheese produced using $100 \%$ of CC (cheese E) had higher points than other cheeses in terms of total sensory scores due to higher points of this cheese in body and texture and odor and flavor during ripening.

\section{CONCLUSIONS}

Use of various combinations of $R$. miehei protease and CC resulted in significant differences between the cheeses in terms of volatile composition and sensory properties especially odor and flavor. Esters and ketones were the main chemical groups of volatile fractions in the cheeses. Use of CC at any level significantly changed the concentrations of acids and alcohols. Furthermore, the concentrations of some compounds including ethyl butanoate, butyl acetate, 2 methylpropyl isobutyrate, isobutyl butanoate, ethyl hexanoate, hexanoic acid, 2-propanone, 2-butanone, 4-octanone, 3-hydroxy-2-butanone, 2-methyl pentanal, 3-methyl-1-butene, methylamine-D2, and toluene were significantly influenced by type and concentration of coagulants. In general, the highest concentrations of volatiles were observed at 90 $\mathrm{d}$ of ripening in all cheeses. Use of higher concentrations of CC resulted in greater sensory scores especially in terms of odor and flavor. In conclusion, the results of

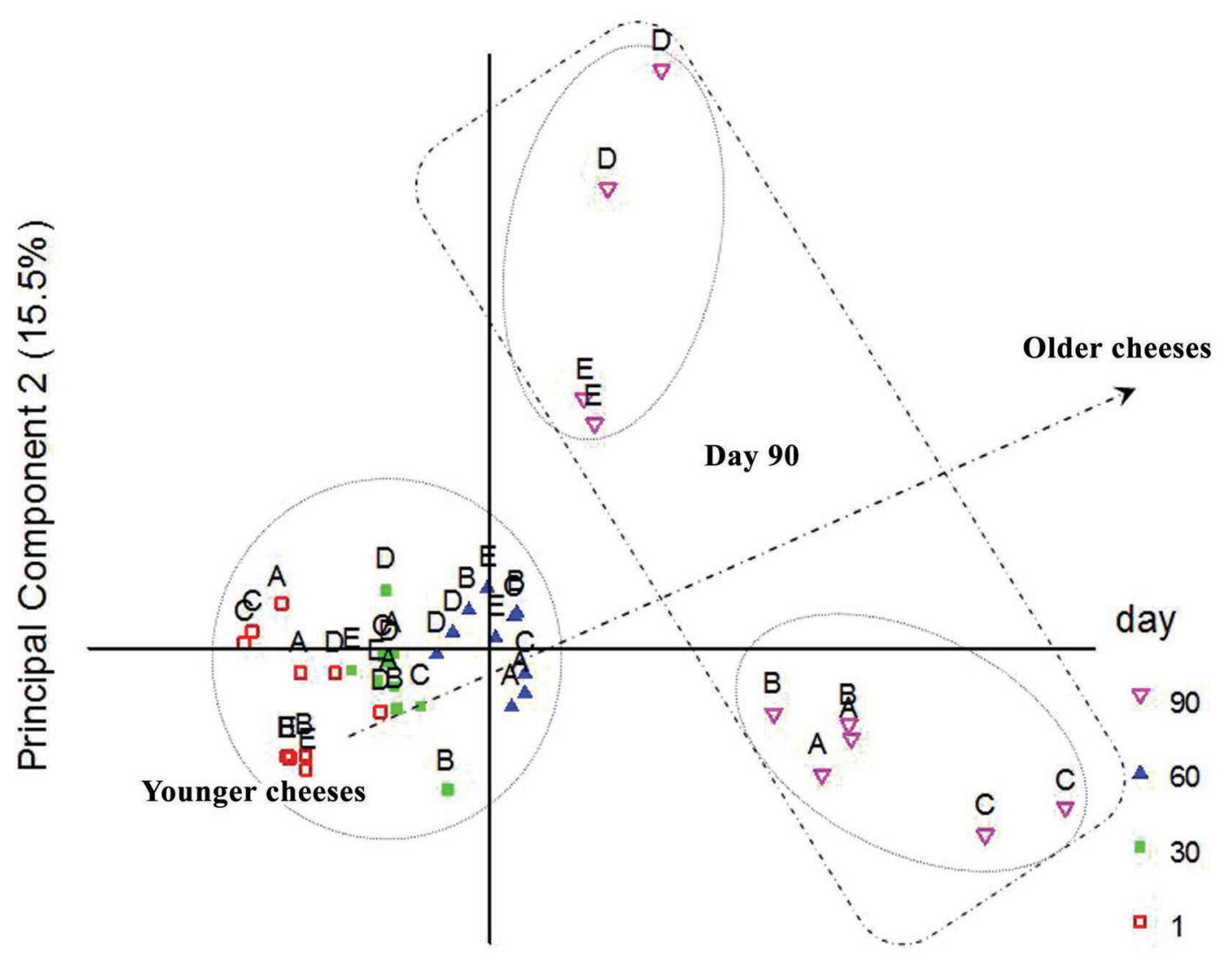

Principal Component 1 (32.3\%)

Figure 1. Score plot of the first 2 principal components of data from GC-MS analysis of Iranian UF white cheeses after d 1 [open square (red)], 30 [solid square (green)], 60 [solid triangle (blue], and 90 [open triangle (purple)] of ripening. The arrow direction shows ripening changes of the cheeses (i.e., from younger cheeses to ripe cheeses). Color version available online. 
Table 6. Sensory evaluation of Iranian UF white cheeses produced from different combinations of Rhizomucor miehei protease and camel chymosin [CC; $100 \%$ of $R$. miehei protease $+0 \%$ of CC (A), $75 \%$ of $R$. miehei protease $+25 \%$ of CC (B), $50 \%$ of $R$. miehei protease $+50 \%$ of CC (C), $25 \%$ of $R$. miehei protease $+75 \%$ of CC (D) and $0 \%$ of $R$. miehei protease $+100 \%$ of CC (E)] during $90 \mathrm{~d}$ of ripening ${ }^{1}$

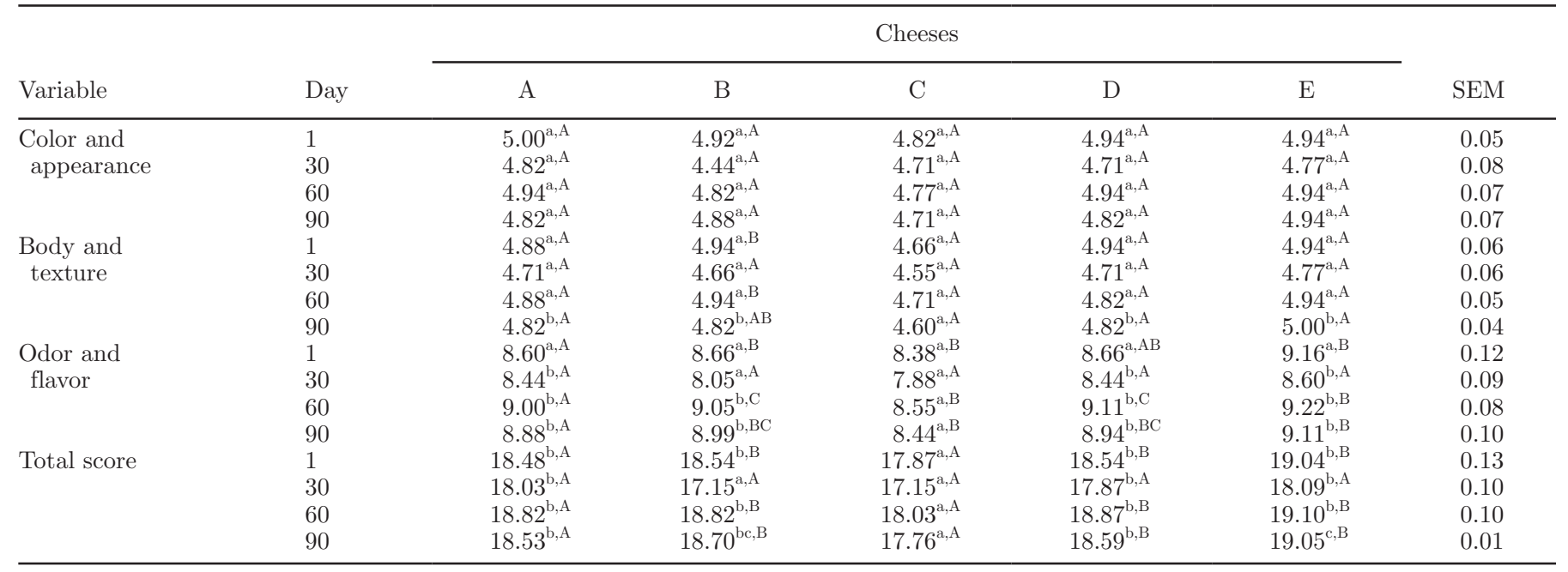

${ }^{\mathrm{a}-\mathrm{c}}$ Means with different superscripts within each sample for each of the parameters measured are different $(P<0.05)$.

${ }^{\mathrm{A}-\mathrm{C}}$ Means with different superscripts within each ripening time for each of the parameters measured are different $(P<0.05)$.

${ }^{1}$ Values are shown as mean of 2 separate samples from 2 batches.

GC-MS and sensory evaluation showed that CC can be completely replaced with $R$. miehei protease during the production of Iranian UF white cheese. Additionally, 2 combinations of $R$. miehei protease and CC (75:25 and 25:75, respectively) can be successfully used for the production of this type of cheese.

\section{ACKNOWLEDGMENTS}

The authors thank the Damaneh Sahand dairy plant (Khosroshah, Tabriz, Iran) for providing raw materials and production equipment for cheese making. The study was partially supported by Inonu University (Malatya, Turkey) Scientific and Research Projects Unit (Project no: $2013 / 30$ ).

\section{REFERENCES}

Al-Otaibi, M. M., and R. A. Wilbey. 2005. Effect of chymosin and salt reduction on the quality of ultrafiltrated white-salted cheese. J. Dairy Res. 72:234-242.

Alizadeh, M., M. Hamedi, and A. Khosroshahi. 2006. Modeling of proteolysis and lipolysis in Iranian white brine cheese. Food Chem. 97:294-301.

Atasoy, A. F., and H. Türkoğlu. 2008. Changes of composition and free fatty acid contents of Urfa cheeses (a white-brined Turkish cheese) during ripening: Effects of heat treatments and starter cultures. Food Chem. 110:598-604.

Attaie, R., and R. Richter. 1996. Formation of volatile free fatty acids during ripening of Cheddar-like goat cheese. J. Dairy Sci. 79:717724 .

Bansal, N., M. A. Drake, P. Piraino, M. L. Broe, M. Harboe, P. F. Fox, and P. L. H. McSweeney. 2009. Suitability of recombinant camel (Camelus dromedarius) chymosin as a coagulant for Cheddar cheese. Int. Dairy J. 19:510-517.
Barbieri, G., L. Bolzoni, M. Careri, A. Mangia, G. Parolari, S. Spagnoli, and R. Virgili. 1994. Study of the volatile fraction of Parmesan cheese. J. Agric. Food Chem. 42:1170-1176.

Bintsis, T., and R. K. Robinson. 2004. A study of the effects of adjunct cultures on the aroma compounds of Feta-type cheese. Food Chem. $88: 435-441$.

Broome, M. C., X. Xu, and J. J. Mayes. 2006. Proteolysis in Cheddar cheese made with alternative coagulants. Aust. J. Dairy Technol. 61:85-87.

Bylund, G. 1995. Dairy Processing. Tetra Pak Processing Systems AB, Lund, Sweden.

Collin, S., M. Osman, S. Delcambre, A. El-Zayat, and J. P. Dufour. 1993. Investigation of volatile flavour compounds in fresh and ripened Domiati cheeses. J. Agric. Food Chem. 41:1659-1663.

Delgado, F. J., J. Gonzalez-Crespo, R. Cava, and R. Ramirez. 2011. Effect of high-pressure treatment on the volatile profile of a mature raw goat milk cheese with paprika on rind. Innov. Food Sci. Emerg. Technol. 12:98-103.

Govindasamy-Lucey, S., Y. Lu, J. J. Jaeggi, M. E. Johnson, and J. A. Lucey. 2010. Impact of camel chymosin on the texture and sensory properties of low-fat Cheddar cheese. Aust. J. Dairy Technol. 65:139-142.

Hayaloglu, A. A., M. Guven, P. F. Fox, and P. L. H. McSweeney. 2005. Influence of starters on chemical, biochemical, and sensory changes in Turkish White-brined cheese during ripening. J. Dairy Sci. 88:3460-3474.

Hayaloglu, A. A., B. Karatekin, and H. Gurkan. 2014. Thermal stability of chymosin or microbial coagulant in the manufacture of Malatya, a Halloumi type cheese: Proteolysis, microstructure and functional properties. Int. Dairy J. 38:136-144.

Hayaloglu, A. A., C. Tolu, K. Yasar, and D. Sahingil. 2013. Volatile and sensory evaluation of goat milk cheese affected by goat breeds (Gokceada and Turkish Saanen) and starter culture systems during ripening. J. Dairy Sci. 96:2765-2780.

Hesari, J., M. R. Ehsani, M. A. E. Mosavi, and P. L. H. McSweeney. 2007. Proteolysis in ultra-filtered and conventional Iranian white cheese during ripening. Int. J. Dairy Technol. 60:211-220.

Hou, J., J. A. Hannon, P. L. H. Mc Sweeney, T. P. Beresford, and T. P. Guinee. 2014. Effect of curd washing on cheese proteolysis, texture, volatile compounds, and sensory grading in full fat Cheddar cheese. Int. Dairy J. 34:190-198. 
Kappeler, S. R., H. J. M. van der Brink, H. Rahbek-Nielsen, Z. Farah, Z. Puhan, E. B. Hansen, and E. Johansen. 2006. Characterization of recombinant camel chymosin reveals superior properties for the coagulation of bovine and camel milk. Biochem. Biophys. Res. Commun. 342:647-654.

Karami, M., M. R. Ehsani, S. M. Mousavi, K. Rezaei, and M. Safari. 2009. Changes in the rheological properties of Iranian UF-Feta cheese during ripening. Food Chem. 112:539-544.

Kaya, S. 2002. Effect of salt on hardness and whiteness of Gaziantep cheese during short-term brining. J. Food Eng. 52:155-159.

Lucey, J. A., M. E. Johnson, and D. S. Horne. 2003. Perspectives on the basis of the rheology and texture properties of cheese. J. Dairy Sci. 86:2725-2743.

Massouras, T., E. C. Pappa, and H. Mallatou. 2006. Headspace analysis of volatile flavour compounds of Teleme cheese made from sheep and goat milk. Int. J. Dairy Technol. 59:250-256.

McSweeney, P. L. H. 2004. Biochemistry of cheese ripening. Int. J. Dairy Technol. 57:127-144.

McSweeney, P. L. H., and M. J. Sousa. 2000. Biochemical pathways for the production of flavour compounds in cheese during ripening: A review. Lait 80:293-324.

Mirzaei, H., H. Pourjafar, and A. Homayouni. 2012. Effect of calcium alginate and resistant starch microencapsulation on the survival rate of Lactobacillus acidophilus La5 and sensory properties in Iranian white brined cheese. Food Chem. 132:1966-1970.

Moynihan, A. C., S. Govindasamy-Lucey, J. J. Jaeggi, M. E. Johnson, J. A. Lucey, and P. L. H. McSweeney. 2014. Effect of camel chymosin on the texture, functionality, and sensory properties of low-moisture, part-skim Mozzarella cheese. J. Dairy Sci. 97:85-96.

Pinho, O., C. Peres, and I. M. P. L. V. O. Ferreira. 2003. Solid-phase microextraction of volatile compounds in "Terrincho" ewe cheese. Comparison of different fibers. J. Chromatogr. A 1011:1-9.
Soltani, M., O. S. Boran, and A. A. Hayaloglu. 2016. Effect of various blends of camel chymosin and microbial rennet (Rhizomucor miehei) on microstructure and rheological properties of Iranian UF White cheese. LWT Food Sci. Technol. 68:724-728.

Soltani, M., N. Guzeler, and A. A. Hayaloglu. 2015. The influence of salt concentration on the chemical, ripening and sensory characteristics of Iranian white cheese manufactured by UF-treated milk. J. Dairy Res. 82:365-374.

Soodam, K., L. Ong, I. B. Powell, S. E. Kentish, and S. L. Gras. 2015. Effect of rennet on the composition, proteolysis and microstructure of reduced-fat Cheddar cheese during ripening. Dairy Sci. Technol. 95:665-686.

Sousa, M. J., Y. Ardo, and P. L. H. McSweeney. 2001. Advances in the study of proteolysis during cheese ripening. Int. Dairy J. 11:327345 .

Sousa, M. J., and F. X. Malcata. 2002. Advances in the role of a plant coagulant (Cynara cardunculus) in vitro and during ripening of cheeses from several milk species. Lait 82:151-170.

Tavaria, F. K., A. C. Silva Ferreira, and F. X. Malcata. 2004. Volatile free fatty acids as ripening indicators for Serra de Estrela cheese. J. Dairy Sci. 87:4064-4072.

Tavaria, F. K., T. G. Tavares, A. C. Silva Ferreira, and F. X. Malcata. 2006. Contribution of coagulant and native microflora to the volatile-free fatty acid profile of an artisanal cheese. Int. Dairy J. $16: 886-894$

Yilmaz, G., A. Ayar, and N. Akin. 2005. The effect of microbial lipase on the lipolysis during the ripening of Tulum cheese. J. Food Eng. 69:269-274.

Yuceer, Y. K., B. Tuncel, O. Guneser, B. Engin, M. Isleten, K. Yasar, and M. Mendes. 2009. Characterization of aroma-active compounds, sensory properties, and proteolysis in Ezine cheese. J. Dairy Sci. 92:4146-4157. 